\title{
EFFECTIVENESS OF THE ACTIVITIES LED IN THE ROMANCE LANGUAGES INTELLIGIBILITY PERSPECTIVE
}

\author{
[EFEKTIVNOST AKTIVIT VYUZITIM METODY \\ INTERKOMPREHENZIE MEDZI ROMANSKYMI JAZYKMI]
}

\author{
Jana Birova - Nina Mockova - Zuzana Simkova - Zdena Kralova - \\ Martina Lipkova
}

\section{doi: 10.18355/PG.2017.6.1.12}

\begin{abstract}
In this paper, we highlight the contribution in the development of plurilingual intercultural competence through learning multiple languages from one language branch - Romance languages. Activities which are the focus of attention of the sampled students are only exploratory. Nevertheless, we motivated students who do not speak more Roman languages to learn these languages simultaneously. We were able to raise their interest and motivation. Within the second activity we have proved that also the literary text may fulfil objectives if the teacher uses correctly the techniques of scaffolding if he or she selects properly the content and harmonizes the global approach to the students' intercomprehension development.
\end{abstract}

\section{Key words}

intelligibility, method, romance languages, teaching, Framework of reference for pluralistic approaches (FREPA), plurilingual intercutural competence (PIC)

\begin{abstract}
Anotácia
V príspevku poukazujeme na prínos v oblasti rozvoja viacjazyčnej interkultúrnej kompetencie prostredníctvom vyučovania viacerých jazykov z jednej jazykovej vetvy - románskej. Aktivity, ktoré sú centrom pozornosti vybranej vzorky žiakov, majú len prieskumný charakter. Napriek tomu sme dokázali motivovat' žiakov, ktorí neovládajú viacero románskych jazykov, aby sa tieto jazyky učili súbežne. Dokázali sme v nich vzbudit' záujem a motiváciu. V druhej aktivite sme dokázali, že aj obt’ažný umelecký text vie naplnit' ciele, ak si učitel' dobre nastaví techniky nápovedy, obsah a zosúladí celkový prístup k rozvoju porozumenia u žiakov.
\end{abstract}

\section{Kl'účové slová}

interkomprehenzia, metóda, románske jazyky, vyučovanie, Referenčný rámec pre integrované vyučovanie jazykov a kultúr (FREPA), viacjazyčná interkultúrna kompetencia (VIK)

\section{Plurilingvizmus \\ Viacjazyčnost' (plurilingvizmus) a jej prínos pre občanov Európskej únie v súčasnom globalizovanom svete patrí medzi čoraz viac diskutované témy. Pri určení jej úlohy v oblasti prebiehajúcich zmien v súvislosti s globalizáciou svetovej ekonomiky, kde sa do popredia dostávajú znalosti a intelektuálny kapitál, má svoje výrazné miesto. Predovšetkým treba zdôraznit' prepojenie jazyka ako pracovnej metódy $\mathrm{s}$ viacjazyčnost’ou, ako strategickým pracovným nástrojom a produktom. \\ V tejto oblasti prebieha viacero výskumov. Ich ciel'om je poukázat' a zdôraznit' význam zručnosti v oblasti ovládania cudzích jazykov v globalizovanom svete, kde sa zvyšuje konkurencia medzi jednotlivými podnikmi, obchodnými zoskupeniami}


a jednotlivými štátmi (Candelier, 2009, Candelier et al., 2011, Byram, 1997, Bialystok, 2007, Coste - Moore - Zarate, 2009, Costa, 2006, Trujillo, 2005).

Potreba podpory viacjazyčnosti súvisí s podporou kultúrnej diverzity, interkultúrnej komunikácie, kultúrnej identity, jazykovej diverzity, ale aj jazykovej príbuznosti. Vzájomná spolupráca závisí od efektívnej komunikácie, ktorá je vo viacerých prípadoch viacjazyčná a závisí tak od viacjazyčnej interkultúrnej kompetencie, ktorú môžu občania EÚ nadobudnút' už počas školskej dochádzky v školách, ktorých je viacjazyčnost' a interkultúrne porozumenie prioritou.

\section{Interkomprehenzia a multilingvizmus}

Jednou z priorít Európskej únie je jej úsilie, ktoré vynakladá na ochranu jazykovej rôznorodosti (multilingvizmus) vrátane vzdelávania v oblasti jazykov. V súčasnosti má štatút úradného jazyka EÚ 24 jazykov, hoci sa v kontinentálnej Európe hovorí viacerými regionálnymi a menšinovými jazykmi. Z hl'adiska zachovania kultúrneho dedičstva, rozmanitosti kultúry a jazyka ako hlavných a jedinečných hodnôt Európy, je potrebné hl'adat' spôsoby vyváženia týchto potrieb a vzájomnej komunikácie. Túto myšlienku odráža aj motto EÚ: ,Jednota v rozmanitosti““. ${ }^{53}$

Tento prístup EÚ k jazykovej rozmanitosti je zakotvený aj v Zmluve o Európskej únii, kde sa v článku 3 hovorí, že „Únia rešpektuje svoju bohatú kultúrnu a jazykovú rozmanitost' a zabezpečuje zachovanie a zvel'ad'ovanie európskeho kultúrneho dedičstva“. ${ }^{54}$ V rámci zvyšovania kultúry a kvality života EÚ sa politika viacjazyčnosti aktívne upriamuje na propagáciu štúdia a používania všetkých svojich úradných jazykov na celom jej území. Jazyková politika Rady Európy charakterizuje viacjazyčný prístup ako proces, $\mathrm{v}$ rámci ktorého sa individuálna jazyková skúsenost' jednotlivca $\mathrm{v}$ jeho kultúrnom kontexte postupne rozširuje od jeho rodného jazyka používaného $\mathrm{v}$ rodine smerom $\mathrm{k}$ jazyku, ktorý používa spoločnost', postupne k jazykom iných národov, čím si buduje viacjazyčnú interkultúrnu kompetenciu (VIK).

V mnohých sférach nášho života sa $\mathrm{v}$ súčasnosti prejavujú zmeny vyplývajúce z procesu globalizácie a integrácie. Je evidentné, že sa čoraz viac upriamuje pozornost' na monopol jediného komunikačného jazyka - anglického. Hladajú sa spôsoby, ktorými by Európa lepšie využila svoju jazykovú rozmanitost' a ako by mala k nej zaujat' konštruktívnejší postoj. Jedným z riešení, ako sa vysporiadat's faktom, že súčasná pozícia angličtiny je vnímaná ako jazyk „lingua franca“v EÚ, je, že sa stane bránou k d’alším jazykom. Aj o to sa pokúša FREPA (Candelier et al., 2011, Candelier, 2009) s definíciou štyroch prístupov k integrovanému vyučovaniu jazykov a kultúr. Pre našu štúdiu sme si zvolili prístup porozumenia medzi románskymi jazykmi - prístup interkomprehenzie, ktorým sme chceli dokázat', že poznanie jedného románskeho jazyka môže byt' cestou k poznávaniu na úrovni porozumenia aj iného románskeho jazyka.

FREPA prístupy si dávajú za ciel' budovat' vo vyučovacom procese u žiakov viacjazyčnú interkultúrnu kompetenciu. Zvolený prístup iniciuje k rozvoju čiastočnej kompetencii jazykového porozumenia prostredníctvom podobných lexikálnych jednotiek, podobných mechanizmov pri tvorbe viet, d'alej podobného pravopisu, príbuznej výslovnosti alebo rovnakých etymologických základov. V prístupe sa

\footnotetext{
${ }^{53}$ Čo je to viacjazyčnost'? [Online]. 2014. In: Európska komisia. [Citované 03.01.2015]. Dostupné na Internete:

http://ec.europa.eu/slovensko/news/viacjazycnost/co_je_viacjazycnost_sk.htm

${ }^{54}$ Konsolidované znenie Zmluvy o Európskej únii a Zmluvy o fungovaní Európskej únie. Charta základných práv európskej únie. [Online]. 2010. [Citované: 03.01.2015]. Dostupné na Internete: http://europa.eu/pol/pdf/qc3209190skc_002.pdf\#page=18
} 
využíva paralelné vyučovanie vo viacerých cudzích jazykoch, ktoré pochádzajú z tej istej jazykovej vetvy ako materinský jazyk (napr. slovenčina, čeština, pol’ština, chorvátčina) alebo z vetvy jazyka, ktorý sa žiak učí (francúzština, taliančina, španielčina). Žiakovi sa vhodnými aktivitami, ktoré splńajú didaktické zásady, otvára priestor na doplnenie vedomostí resp. zaktivizovanie porozumenia medzi románskymi jazykmi.

\section{Výskumná otázka}

Budú sa účastníci prieskumu aktívne zapájat' do aktivít obsahujúcich slovné jednotky z viacerých jazykov z románskej vetvy jazykov? Dokážu svojou aktívnou účast'ou napnit' ciele vyplávajúce zo zadaní a z obsahu aktivít?

\section{Metódy}

Ako prvú metódu výskumu sme použili metódu kvalitatívneho výskumu pozorovanie, ktorým sme dospeli k hodnoteniu efektívnosti implementácie aktivít. Boli použité tiež matematické metódy súčtu a pomeru celkového času a mapovanie interakcií podl'a príslušných vzorcov.

Ďalšou použitou metódou bola metóda obsahovej analýzy - kvalitatívne hodnotenie ciel'ov a aktivity prostredníctvom deskriptorov rámca FREPA (Candelier et al., 2009, 2011), ktoré sú určené na takéto hodnotenie.

\section{Vzorka prieskumu a priebeh}

Prieskumu sa zúčastnili žiaci posledných ročníkov gymnázií v počte 12 z rôznych stredných škôl pri príležitosti projektu Minierazmus 2016 na Pedagogickej fakulte Univerzity Komenského v Bratislave.

\section{Aktivita (̌̌.1) s názvom Bystré oko}

Kognitívny ciel' : zatriedit' slová, ktoré sa graficky podobajú.

Afektívny ciel': práca v skupinách, spolupráca.

Trvanie: 10 minút

Použitý materiál:

\begin{tabular}{|l|l|l|l|}
\hline \multicolumn{1}{|c|}{ anglicky } & \multicolumn{1}{c|}{ španielsky } & \multicolumn{1}{c|}{ francúzsky } & fansky \\
\hline family & familia & famille & famiglia \\
\hline mother & madre & mère & madre \\
\hline student & estudiante & étudiant & studente \\
\hline telephone & teléfono & téléphone & telefono \\
\hline decide & decidir & décider & decidere \\
\hline shampoo & champú & shampooing & shampoo \\
\hline bus & autobús & autobus & autobus \\
\hline visit & visitar & visiter & visitare \\
\hline guitar & guitarra & guitare & chitarra \\
\hline guide & guía & guide & guida \\
\hline school & escuela & école & scuola \\
\hline temperature & temperatura & température & temperatura \\
\hline industry & industria & industrie & industria \\
\hline photography & fotografia & photographie & fotografia \\
\hline article & artículo & article & articolo \\
\hline theatre & teatro & théâtre & teatro \\
\hline language & lenguaje & langue & lingua \\
\hline music & música & musique & musica \\
\hline grammar & gramática & grammaire & grammatica \\
\hline
\end{tabular}


Metodický postup:

Táto aktivita je určená pre prácu v skupinách s počtom žiakov $3-5 \mathrm{v}$ každej skupine. Všetky skupiny dostanú od učitel'a rovnaké kartičky, na ktorých je napísaných $15-20$ slov v troch románskych jazykoch - španielčina, francúzština, taliančina. Slová sú pomiešané a nepochádzajú z jedného tematického celku. Podmienkou však je, aby medzi všetkými slovami existovala ortografická podoba (napr. estudiante (špan.) étudiant (fran.) - studente (tal.)). Každá skupina bude mat' pred sebou na laviciach rozložené v stĺpci nal'avo kartičky s anglickými ekvivalentami slov. Opät' musí jestvovat' ortografická podobnost' medzi slovom v románskych jazykoch a v angličtine (vid'. príklad student (ang.)).

Ako malú zahrievaciu aktivitu pred začatím samotnej úlohy a ešte pred zadaním inštrukcií môže učitel' voviest' žiakov do témy tak, že povie nejaké slovo napríklad v angličtine a opýta sa žiakov, aký ekvivalent mu zodpovedá v románskom jazyku, ktorý ovládajú, zároveň, či by vedeli aj ekvivalent vo zvyšných dvoch románskych jazykoch. Tu však musí učitel' zvolit' také slovo, o ktorom sa predpokladá, že väčšina žiakov pozná (napr. z oblasti gastronómie, hudby, filmu, a pod.) a jeho ekvivalenty musia byt' tak isto pravopisne podobné. Učitel' môže dat' takéto slovíčka dve (v angličtine), alebo jedno a druhé nechat' vymysliet' žiakov. Vd’aka takejto malej predaktivite si žiaci možno uvedomia vzájomnú podobnost' medzi jazykmi (aj takými, ktoré neovládajú), ktorú si častokrát ani neuvedomujú, hoci sa s týmto javom stretávajú bežne v živote. Aktivita, ktorá potom bude nasledovat', im tak príde zaujímavejšia.

Učitel' po rozdaní kartičiek oboznámi žiakom s ciel’om aktivity: na základe pravopisnej podobnosti slov priradit' k anglickým slovám zodpovedajúce ekvivalenty vo všetkých troch románskych jazykoch. Skupina, ktorá bude mat' správne priradených najviac slov, vyhráva. Pomôckou im môže byt' angličtina ako východiskový jazyk, nakol'ko predpokladáme, že žiaci stredných škôl na Slovensku ovládajú anglický jazyk v rozpätí úrovní A1 - B2 podl’a Spoločného európskeho referenčného rámca. Ked’že táto aktivita je určená žiakom, ktorí už ovládajú jeden románsky jazyk (aspoň na začiatočníckej úrovni), tento im tak isto môže byt' oporou pri zatried'ovaní slov. Žiaci sa tak vedia opriet' o dva jazyky, takže úloha by pre nich nemala predstavovat' až taký vel'ký problém, hoci d'alšie dva románske jazyky neovládajú vôbec. To im zároveň pomôže prekonat' strach z neznáma, ktorý môžu výraznejšie pocit'ovat' najmä žiaci, ktorí si menej veria. Počas práce na zadanej úlohe, rola učitel'a spočíva v monitorovaní celej aktivity: akonáhle začnú žiaci na zadaní pracovat', učitel' im môže ul'ahčit' prácu tým, že im poradí, aby si pomiešané kartičky najskôr rozložili, aby tak získali lepší prehl'ad o slovách, s ktorými majú pracovat'; alebo že je dobré vopred si určit' vedl'a anglického stípca poradie d'aších stípcov (napr. španielsky - francúzsky - taliansky), aby sa im jazyky neskôr nemýlili; alebo ich môže posmelit', že je dobré sa pohybovat' okolo lavice, čo im umožní efektívnejšie operovat's množstvom rozložených slov. Ide o aktivitu trochu náročnejšiu na priestor, čiže je optimálne, aby bol v triede okolo lavíc dostatočný priestor, aby sa žiaci mohli pohybovat'. Učitel' monitoruje aj priebeh práce žiakov, môže ich priamo počas práce v určitej fáze upozornit' na niektoré spoločné znaky, ktoré sú charakteristické pre tenktorý románsky jazyk. Táto technika pedagogickej nápovedy im poslúži pre l’ahšie sa orientovanie $\mathrm{v}$ jazyku, ktorý nepoznajú. Napríklad ich môžeme upozornit' na určité špecifické znaky vo francúzskych slovách: napr. na /ç/, /è/, /ê/ vo francúzštine či /ñ/ $\mathrm{v}$ španielčine, alebo na zakončenie infinitívu slovies v taliančine na -re.

\section{Zhodnotenie efektívnosti aktivít a diskusia}

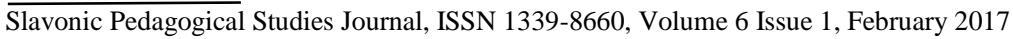




\begin{tabular}{|l|l|}
\hline Aktivita č. 1 - Realizácia & $\begin{array}{l}\text { Žiaci z rôznych stredných škôl, } 2016 \\
\text { Počet: } 12\end{array}$ \\
\hline $\begin{array}{l}\text { Naplánované učebné činnosti boli splnené v rámci vyučovacej jednotky. Prepojenie } \\
\text { edukačných ciel'ov, učebných činností a sebahodnotenia sa uskutočnilo. Učebné a } \\
\text { motivačné ciele boli splnené. Žiaci pracovali na podnet učitel'a. }\end{array}$
\end{tabular}

Aktivita č. 1 - Reflexia

Pozitíva: motivácia žiakov bola dosiahnutá netradičnou formou práce, žiaci aktivizovali na základe techniky grafickej podobnosti svoje kapacity pre prozumenie iných románskych jazykov. zaznamenali sme spoluprácu medzi žiakmi, ktorí sa medzi sebou nepoznali, nakol'ko prišli iba na pár dní v rámci projektu Minierazmus. Ďalej sme zaznamenali motiváciu týchto žiakov, ktorá bola dosiahnutá na základe úspechu v učebnej činnosti. Úspech vo vykonaní činnosti, ktorá sa spájala s ciel'om vyučovacej jednotky - porozumením medzi viacerými románskymi jazykmi a angličtinou.

\section{Prínos - zisky pre žiaka:}

rozvoj aktívneho čítania s porozumením medzi románskymi jazykmi, kritického, hodnotiaceho a tvorivého myslenia, rozvoj prezentačných schopností, fixácia vedomostí vizuálnou recepciou, spätná väzba iných žiakov a učitel'a, vzájomné učenie sa, sebahodnotenie, motivácia Prínos - zisky pre učitel'a:

spätná väzba o možnostiach rozvoja takéhoto vyučovania $\mathrm{v}$ iných školách, možnost' plnit' si funkciu pozorovatel'a, facilitátora, manažéra, možnost' poskytovat' individuálnu pomoc, možnost' formatívneho hodnotenia (slovné ocenenie výkonov žiakov a oprava chýb)

Negatíva: obmedzená slovná zásoba, nekomunikatívny typ žiakov - prenechávali iniciatívu komunikatívnejšie zdatnejším žiakom

Úskalím aktivity je jej lexikálne ohraničenie ako aj to, že jednotlivé slová nenachádzajú uplatnenie v kontexte a v komunikácii.

Riziká: počas práce $\mathrm{v}$ skupine, riziko spolupráce obmedzené, žiaci stojaci vzadu znevýhodnení a málo aktívni, tendencia používat’ materiský jazyk, spájanie do dvojíc a nie pracovných skupín, riziko kognitívnej dizonancie, riziko blokov pri počúvaní zadania

Je dôležité, aby učitel' nenechal pracovat' žiakov, pokial' aspoň jedna skupina nebude mat' priradené všetky slová, pretože by to mohlo trvat' zbytočne dlho, aktivita by sa tak mohla žiakom zdat' zdíhavá až nudná a tak isto by sa tým pádom vytratila prirodzene sút'aživá stránka a dynamickost'. Preto je vhodné, aby učitel' hned' na začiatku spolu s úvodnými inštrukciami stanovil čas (napr. $10 \mathrm{~min}$; v závislosti od počtu slov a žiakov v skupinách). Môže sa stat', že ani jedna skupina nestihne priradit' všetky slová v časovom limite, čo však nepredstavuje žiaden problém, ked’že hlavným ciel'om nie je len byt' najrýchlejší, ale určit' čo najviac slov správne. Po uplynutí stanoveného času nasleduje vyhodnotenie aktivity: nahlas sa spoločne kontrolujú slová (optimálne riadok po riadku, čiže jedno slovo vo všetkých jazykoch, atd'.), prípadne sa komentujú chyby a pod. Bolo by vhodné, aby vždy nejaký žiak nahlas prečítal jeden riadok, a to z dôvodu, aby si všimli aj zvukovú stránku slov. Učitel' zapisuje na tabul'u bod za každý správne zaradený riadok. Vyhráva skupina s väčším počtom bodov.

Efektívnost' aktivity bola sumarizovaná podl'a vzorca:

\section{$\Sigma \mathrm{Tt} / \mathrm{i}: \Sigma \mathrm{Si}$}

Znamená to, že počas 10 - minutového trvania aktivity sme zmerali pomer súčtu učitel'ovej aktivity, interakcie a komunikácie (Tt/i) so súčtom aktivity žiakov (Si). Aktivita je: 
- efektívna, ak $\mathrm{Tt} / \mathrm{i}<\mathrm{Si}$, čiže ak $\mathrm{Tt} \leq 2$ minúty,

- málo efektívna, čiže ak Tt/i = 3 až 5 minút alebo neefektívna, ak Tt/i $\geq \mathrm{Si}$, čiže ak $\mathrm{Tt} / \mathrm{i} \geq 5$ minút (polovica trvania aktivity).

V aktivite 1 sme dospeli $\mathrm{k}$ záveru, že bola efektívna, ked’že učitel'ova aktivita, interkacia a komunikácia bola pod 2 minúty z celkového času trvania aktivity a aktivita študentov bola nad 8 minút.

$\Sigma 1^{\prime} 46 \mathrm{Tt} / \mathrm{i}: \Sigma 8^{\prime} 14 \mathrm{Si}$

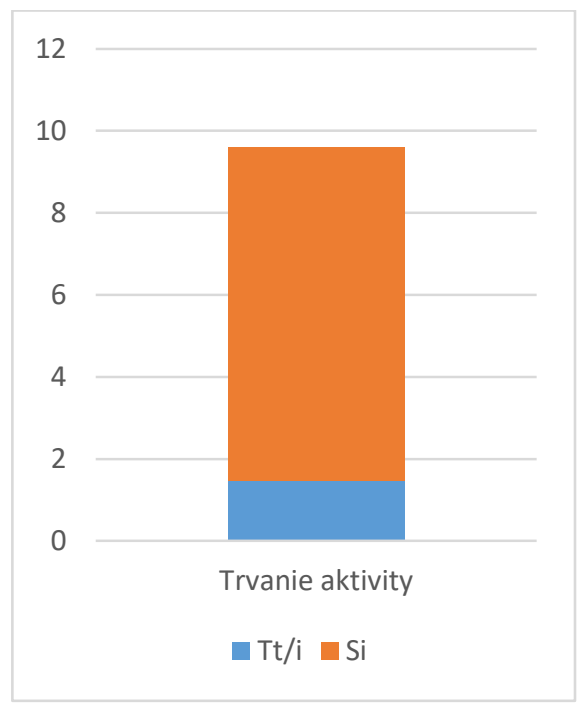

Celkovo možno konštatovat', že efektívnost' aktivity sa prejavila aj správnym a rýchlym zatriedením slov a že do aktivity sa zapojili všetci žiaci.

\section{Aktivita (̌̌. 2) s názvom Bájka}

Kognitívny ciel' : zatriedit' slová, ktoré sa graficky podobajú a majú ten istý význam, preložit' bájku do slovenčiny a identifikovat' slová v troch románskych jazykoch.

Afektívny ciel': práca v skupinách, spolupráca.

Ďalšie ciele - vid' analýza ciel'ov podl'a FREPA.

Trvanie: 20 minút

Použitý materiál:

\section{La zorra y el cuervo gritón}

Un cuervo robó a unos pastores un pedazo de carne y se retiró a un árbol.

Lo vio una zorra, y deseando apoderarse de aquella carne empezó a halagar al cuervo, elogiando sus elegantes proporciones y su gran belleza, agregando además que no había encontrado a nadie mejor dotado que él para ser el rey de las aves, pero que lo afectaba el hecho de que no tuviera voz.

El cuervo, para demostrarle a la zorra que no le faltaba la voz, soltó la carne para lanzar con orgullo fuertes gritos. 
La zorra, sin perder tiempo, rápidamente cogió la carne y le dijo: "Amigo cuervo, si además de vanidad tuvieras entendimiento, nada más te faltaría realmente para ser el rey de las aves."

\section{Il corvo e la volpe}

Un corvo aveva rubato un pezzo di carne ed era andato a posarsi su di un albero. Lo vide la volpe e le venne voglia di quella carne. Si fermò à suoi piedi e cominciò ad adularla, facendo grandi lodi del suo corpo perfetto e della sua bellezza, della lucentezza delle sue penne, dicendo che nessuno era più adatto dì lui ad essere il re degli uccelli, e che lo sarebbe diventato senz'altro, se avesse avuto la voce.

Il corvo, allora, volendo mostrare che neanche la voce gli mancava, si mise a gracchiare con tutte le sue forze, e lasciò cadere la carne.

La volpe si precipitò ad afferrarla e beffeggiò il corvo soggiungendo: " $\mathrm{Se}$, poi, caro il mio corvo, tu avessi anche il cervello, non ti mancherebbe altro, per diventare re".

\section{Le corbeau et le renard}

Un corbeau, ayant volé un morceau de viande, s'était perché sur un arbre. Un renard l'aperçut, et, voulant se rendre maître de la viande, se posta devant lui et loua ses proportions élégantes et sa beauté, ajoutant que nul n'était mieux fait que lui pour être le roi des oiseaux, et qu'il le serait devenu sûrement, s'il avait de la voix.

152 Le corbeau, voulant lui montrer que la voix non plus ne lui manquait pas, lâcha la viande et poussa de grands cris.

Le renard se précipita et, saisissant le morceau, dit : " $\hat{O}$ corbeau, si tu avais aussi du jugement, il ne te manquerait rien pour devenir le roi des oiseaux. "

\section{Metodický postup:}

Materiál k aktivite je rozdaný do každej sút’ǎnej skupiny s počtom žiakov $3-5$. Ked’že žiaci ovládali prevažne anglický jazyk, niektorí z nich ovládali francúzsky jazyk a niektorí z nich španielsky, učitel' roztriedil žiakov do štyroch pracovných skupín. Skupiny žiakov, ktorí ovládali francúzsky jazyk, dostali materiál spracovaný tak, že z troch pracovných textov bol integrálny len text po francúzsky. Nachádzali sa v ňom vyžltené slovíčka, ktoré mali vyhl'adat' a zatriedit' v ostatných dvoch textoch $\mathrm{v}$ talianskom a španielskom. Naopak skupiny, ktorých silným jazykom bol španielsky, dostali integrálny text $\mathrm{v}$ španielskom jazyku a úloha bola hl'adat' slovíčka $\mathrm{v}$ iných dvoch jazykoch.

Žiakom bolo v aktivite 1 ukázané, akým spôsobom majú pristupovat' k neznámym jazykom. Predpokladali sme, že okrem anglického jazyka, aktívneho románskeho jazyka sa nezl'aknú ani práce $\mathrm{s}$ inými románskymi jazykmi v kontexte bájky literárneho textu. napomôže im to ešte väčšmi prekonat' strach z neznáma, ktorý môžu výraznejšie pocit'ovat' najmä žiaci, ktorí si menej veria. Rozličné techniky pedagogickej nápovedy musia byt' pri prvotnom vyučovaní súčast'ou učitel'ovej práce: učitel' aj tu monitoruje priebeh celej aktivity: akonáhle začnú žiaci na zadaní pracovat', učitel' im môže ul'ahčit' prácu tým, že im radí v hl'adaní súvislostí, v hl'adaní synoným v silnom jazyku a ich odvodením pre iné dva jazyky. Príkladom môže byt' napríklad slovo viande vo francúzštine, ktoré v textoch má ekvivalent carne. Pomocným slovíčkom vo francúzštine tak môže byt' carnivore (mäsožravý). 
Učitel'ova práca nespočíva $\mathrm{v}$ predkladaní celých návrhov riešenia dorozumievacích problémových aktivít, ale $\mathrm{v}$ náznakoch či nápovedách, pomocou ktorých si žiak aktivizuje svoje kognitívne a metakognitívne procesy. Učitel' môže v určitej fáze upozornit' na niektoré spoločné znaky, ktoré sú charakteristické pre románske jazyky. Napríklad ich môžeme upozornit' na určité špecifické znaky vo francúzskych slovách: /ç/, /è/, /ê/ vo francúzštine či / $\tilde{n} /$ v španielčine, alebo na zakončenie infinitívu slovies $\mathrm{v}$ taliančine $-r e$.

\section{Zhodnotenie efektívnosti aktivít a diskusia}

\begin{tabular}{|c|c|}
\hline $\mathrm{a}$ & \\
\hline \multicolumn{2}{|c|}{$\begin{array}{l}\text { Naplánované učebné činnosti boli splnené v rámci vyučovacej jednotky. Prepojenie } \\
\text { edukačných ciel'ov, učebných činností a sebahodnotenia sa uskutočnilo. Učebné a } \\
\text { motivačné ciele boli splnené. Žiaci pracovali na podnet učitel'a. }\end{array}$} \\
\hline \multicolumn{2}{|l|}{ Aktivita č. 1 - Reflexia } \\
\hline \multicolumn{2}{|c|}{$\begin{array}{l}\text { Pozitíva: motivácia žiakov bola dosiahnutá netradičnou formou práce, žiaci } \\
\text { aktivizovali na základe techniky grafickej podobnosti svoje kapacity pre prozumenie } \\
\text { iných románskych jazykov, zaznamenali sme spoluprácu medzi žiakmi, ktorí sa medzi } \\
\text { sebou nepoznali, nakol'ko prišli iba na pár dní v rámci projektu Minierazmus. Ďalej } \\
\text { sme zaznamenali motiváciu týchto žiakov, ktorá bola dosiahnutá na základe úspechu } \\
\text { v činnosti. }\end{array}$} \\
\hline & \\
\hline $\begin{array}{l}\text { rozvoj aktívneho čítania s porozumením } \\
\text { medzi románskymi jazykmi, kritického, } \\
\text { hodnotiaceho a tvorivého myslenia, } \\
\text { rozvoj prezentačných schopností, fixácia } \\
\text { vedomostí vizuálnou recepciou, spätná } \\
\text { väzba iných žiakov a učitel'a, vzájomné } \\
\text { učenie sa, sebahodnotenie, motivácia }\end{array}$ & $\begin{array}{l}\text { spätná väzba o možnostiach rozvoja } \\
\text { takéhoto vyučovania v iných školách, } \\
\text { možnost' plnit' si funkciu pozorovatel'a, } \\
\text { facilitátora, manažéra, možnost' } \\
\text { poskytovat' individuálnu pomoc, možnost' } \\
\text { formatívneho hodnotenia (slovné } \\
\text { ocenenie výkonov žiakov a oprava chýb) }\end{array}$ \\
\hline \multicolumn{2}{|c|}{$\begin{array}{l}\text { Negatíva: obmedzená slovná zásoba, prezentácia slovnej zásoby, ktorá sa graficky } \\
\text { podobá ale aj slovnej zásoby, ktorá je úplne odliná, nekomunikatívny typ žiakov - } \\
\text { prenechávali iniciatívu komunikatívne zdatnejším žiakom, umelecký text - t’ažká } \\
\text { syntax, zložité minulé časy, archaizmy. }\end{array}$} \\
\hline \multicolumn{2}{|c|}{$\begin{array}{l}\text { Riziká: silná preferencia používania materinského jazyka ako výskumného } \\
\text { a dorozumievacieho jazyka, počas práce v skupinách nesprávne rozdelenie úloh, } \\
\text { aktívni žiaci vel'mi aktívni, žiaci, ktorí by potrebovali viac času k premýlaniu boli } \\
\text { pozadu, spájanie do dvojíc a nie pracovných skupín, riziko kognitívnej dizonancie, } \\
\text { riziko blokov pri riešení viacjazyčného zadania, pri nesprávnych technikách nápovedy } \\
\text { sa objaví riziko úplnej demotivácie riešit' úlohu, riziká demotivácie spôsobené } \\
\text { prehoru v sút'aži. }\end{array}$} \\
\hline
\end{tabular}

Efektívnost’ aktivity bola sumarizovaná podl'a vzorca:

$$
\Sigma \text { IT }: \Sigma \text { IS }\{\text { IS } 1 \leftrightarrow 2 \leftrightarrow 3\}+\{\text { IS } 4 \leftrightarrow 5 \leftrightarrow 6\}+\{\text { IS } 7 \leftrightarrow 8 \leftrightarrow 9\}+\{\text { IS } 10 \leftrightarrow 11 \leftrightarrow 12\}
$$

Znamená to, že počas 20 - minutového trvania aktivity sme zmerali pomer súčtu učitel'ovej aktivity, interakcie a komunikácie (Tt/i) so súčtom interakcií dvanástich žiakov (IS1↔12), ktoré sú zaznamenávané pozorovatel'om do hárku interakčných schém. Aktivita je:

- efektívna, ak Tt/i < IS1-12 a IS v troch až štyroch skupinách sú prelinkované aspoň trikrát, 
- málo efektívna, ak Tt/i = IS1-12 a aspoň v dvoch skupinách nie sú interakcie alebo neefektívna, ak Tt/i $\geq$ IS1-12 a aspoň v troch skupinách nie sú interakcie.

Celková úspešnost' aktivity je meraná binárnym typom úlohy a teda správne zodpovedanými položkami, ktorými sú slová vytriedené z kontextu.

V aktivite 2 sme dospeli k záveru, že aktivita bola efektívna, ked’že

$$
\begin{gathered}
\{\text { IS } 1 \leftrightarrow 2=3 x ; \text { IS } 2 \leftrightarrow 3=4 x ; \text { IS } 1 \leftrightarrow 3=2 x\} \\
\{\text { IS } 4 \leftrightarrow 5=5 x ; \text { IS } 5 \leftrightarrow 6=2 x ; \text { IS } 6 \leftrightarrow 4=4 x\} \\
\{\text { IS } 7 \leftrightarrow 8=3 x ; \text { IS } 8 \leftrightarrow 9=2 x ; \text { IS } 7 \leftrightarrow 9=4 x\} \\
\{\text { IS } 10 \leftrightarrow 11=1 x ; \text { IS } 11 \leftrightarrow 12=7 x ; \text { IS } 10 \leftrightarrow 12=1 x\} \\
\text { IIT }(3): \Sigma \text { IS }\{9\}+\{11\}+\{9\}+\{9\}=(38)
\end{gathered}
$$

Celkovo možno konštatovat', že efektívnost' aktivity sa prejavila aj správnym a rýchlym zatriedením slov a že do aktivity sa zapojili všetci žiaci. Z interakcií $\mathrm{v}$ skupinách možno badat', že prebiehali v troch skupinách skoro rovnako. V poslednej skupine badat', že žiak 10 viedol iba dve interakcie, jednu so žiakom 11 a jednu so žiakom 12. Úloha bola $\mathrm{v}$ každej skupine zodpovedaná $\mathrm{s}$ úspešnost'ou $\mathrm{v} 1$. skupine 11 správne zatriedených slov, v 2. skupine 13 slov, v 3. skupine 10 slov a v 4 . skupine 9 slov.

Z chýb možno konštatovat', že problémy s porozumením spôsobila v troch skupinách ekvivalencia oslovenia

Amigo cuervo - caro il mio corvo - Ô corbeau.

Z preukázaných mediačných schopností počas pozorovania možno spomenút' parafrázovanie, redukciu textu, kalky $\mathrm{v}$ úrovni morfológie, napríklad používanie prechodníka v slovenčine chcúc.

Pri hl'adaní slov, ktoré sa graficky nepodobajú, mali žiaci pracovných skupín najväčšie problémy s identifikáciou týchto slov: perder tiempo, Naopak žiaci boli aktívni pri hl'adaní ekvivalentov vo francúzštine zo slov, ktoré boli v d’alších dvoch textoch spomenuté, ale neboli preložené vo francúzštine hl'adaným synonymom:

con tutte le sue forze - avec/de toute la force, caro mio - mon cher, se retiró - s'est retiré.

Obsaová analýza ciel’ov a aktivít Referenčným rámcom pre integrované vyučovanie jazykov a kultúr (Candelier et al., 2011). Aktivitám boli pridelené tieto deskriptory FREPA:

$\mathrm{K}$ - 1.2.2 Vediet', že dve slová identického tvaru (alebo ktoré sa v rôznych jazykoch podobajú), nemajú nevyhnutne rovnaký význam

$\mathrm{K}-1.3 .1$ Vediet', že uprostred tej istej jazykovej komunity jednotlivci prisudzujú približne rovnaký význam tým istým tvarom

$\mathrm{K}-1.6$ Vediet', že existujú rozdiely medzi jazykom písaným a ústnym

$\mathrm{K}$ - 2 Poznat' úlohu spoločnosti vo fungovaní jazykov, resp. úlohu jazykov vo fungovaní spoločnosti

K - 3.4.1 Vediet', že na ul'ahčenie komunikácie možno nadviazat' na jazykové podobnosti (genealogické väzby, prevzaté znaky, univerzálne javy)

K - 4.1 Vediet', že jazyky sú navzájom prepojené príbuzenskými vzt’ahmi, resp. vediet', že existujú ,jazykové rodiny“

$\mathrm{K}$ - 4.1.1 Poznat' niekol'ko jazykových rodín a niektoré jazyky, ktoré sú ich súčast'o

$\mathrm{K}$ - 4.2 Mat' vedomosti o znakoch/ javoch prevzatých z jedného jazyka do druhého 
K - 4.2.1 Mat' poznatky o podmienkach, za ktorých sa uskutočňujú slovné výpožičky (kontaktná situácia, terminologické potreby spojené s novými produktami, novými technikami, účinky doby...)

$\mathrm{K}-4.3$ Poznat' určité prvky z histórie jazykov (pôvod týchto jazykov, ich vývoj v lexike, fonologický vývoj ...

$\mathrm{K}$ - 5 Mat' vedomosti o rôznorodosti jazykov (multilingvizmus, plurilingvizmus)

$\mathrm{K}-6.4$ Vediet', že aj ked' sa tieto kategórie nachádzajú i v inom jazyku, nie sú nevyhnutne organizované rovnakým spôsobom

$\mathrm{K}$ - 6.9.3 Vediet', že príbuzné zvuky môžu viest' k úplne inému spôsobu písania v rôznych jazykoch

$\mathrm{K}$ - 6.9.4 Vediet', že v abecednom systéme každého jazyka vzt'ah graféma - fonéma je špecifický

K - 7.1 Poznat' niektoré všeobecné zásady, ako sa učíme jazykom hovorit'

$\mathrm{K}-7.1 .2$ Vediet', že robit' chyby je prirodzené, kým ešte jazyk neovládame

$\mathrm{K}$ - 7.1.3 Vediet', že svojím správaním je možné pomôct' tomu, kto sa učí, ale je tiež

možné „zablokovat"“ ho, ak ho bez prestania opravujeme, alebo sa $\mathrm{z}$ neho vysmievame

$\mathrm{K}$ - 7.1.4 Vediet', že nikdy jazyk nebudeme ovádat' celistvo a že bude množstvo náležitostí, ktoré nevieme, v ktorých sa môžeme zdokonal'ovat'

$\mathrm{K}$ - 7.2 Vediet', že pri učení jazykov sa môžeme opriet' o podobnosti (štrukturálne, diskurzívne, pragmatické)

$\mathrm{K}$ - 7.3 Vediet', že jazyky sa môžeme lepšie naučit', ak nadobudneme pozitívny postoj voči jazykovým rozdielom

$\mathrm{K}$ - 7.4 Vediet', že predstava, ktorú máme o jazyku, ovplyvňuje proces učenia

$\mathrm{K}-7.5$ Vediet', že existujú rôzne stratégie učenia sa jazykov a že nie všetky majú rovnako podstatný význam vo vzt'ahu k daným ciel’om

K - 7.5.1 Poznat' niekol'ko stratégií učenia sa a ich význam (počúvat' a opakovat', prepisovat' viackrát, prekladat', pokúsit' sa tvorit' vety...)

$\mathrm{K}-7.6$ Vediet', že je užitočné dobre poznat' stratégie, ktoré používame, aby sme ich mohli prispôsobit' svojim ciel'om

A - 1.1.2 Zvážit', chápat' jazykové a kultúrne prvky ako predmet pozorovania či úvahy

A - 2 Vnímavost' existencie iných jazykov, kultúr, osôb a existencie rôznorodosti jazykov, kultúr a osôb

A - 2.2.1.1 Byt' citlivý voči rôznorodosti jazykových svetov (zvukové formy, grafické formy, syntaktické štruktúry, atd'.) a kultúrnych svetov (spôsoby stolovania, pravidlá dopravy, atd'.)

A - 2.2.3 Vnímat' odlišnosti v jazyku (napr. v slovách vypožičaných z iných jazykov) a v kultúre

A - 2.3 Cit pre jazykové a kultúrne podobnosti

A - 3 Zvedavost' (záujem) o cudzie jazyky, kultúry, osoby, d’alej o multikultúrny kontext, jazykovú, kultúrnu, l'udskú rôznorodost' prostredia a o jazykovú, kultúrnu a l'udskú rôznorodost' vo všeobecnosti

A - 4 Pozitívne akceptovanie jazykovej a kultúrnej rôznorodosti iného (rozdielneho) A - 4.3.1 Prijat' fakt, že existujú zvuky, „fonémy“, prozodické a prízvučné formy odlišné od tých, ktoré sú vo vlastnom jazyku

A - 4.3.2 Pripustit', že existujú znaky a typografické prvky, ktoré sa odlišujú od tých vo vlastnom jazyku (používanie úvodzoviek, označovanie prízvuku, "ß" v nemčine, atd'.)

A - 5 Otvorenost' pre diverzitu jazykov, osôb a kultúr sveta a pre diverzitu ako takú (pre inakost' seba a pre inakost' ako takú)

A - 5.3.2 Otvorenost' voči cudzím jazykom a kultúram vyučovaných v škole

A - 5.3.3 Otvorenost' voči (jazykovému alebo kultúrnemu) neznámemu 
A - 5.3.3.1 Byt' otvorený (a ovládat' svoju vlastnú potenciálnu vytrvalost') voči tomu, čo sa zdá nezrozumitel'né a odlišné

A - 6.2.1 Zobrat' do úvahy, že výpožičky z iných jazykov či kultúr sú súčast'ou reality jedného jazyka (kultúry) a prispievajú k jeho obohateniu

A - 6.5.2 Považovat' každý jazyk a kultúru za prostriedok l'udského rozvoja, sociálneho začlenenia a chápat' ho ako podmienku na výkon štátneho občianstva

A - 7.3.1 Schopnost' čelit' (s dôverou) tomu, čo je nové, cudzie v jazykovom a kultúrnom správaní či v kultúrnych hodnotách iného

A - 8.2 Vedome sa zúčast'novat' na tvorbe vlastnej viacjazyčnej interkultúrnej kompetencie. Dobrovol'ne sa angažovat' v rozvoji viacjazyčnej viackultúrnej socializácii

A - 9.1 Ochota klást' otázky, týkajúce sa jazykov a kultúr

A - 14.3.1 Mat' sebadôveru $\mathrm{v}$ svoje schopnosti pozorovat', analyzovat' známe i neznáme jazyky

A - 18 Motivácia učit' sa jazyky (školský jazyk, jazyk používaný v rodine, cudzie jazyky, regionálne jazyky...)

A - 18.1 Pozitívny postoj voči učeniu sa jazykov (a voči tým, ktorí nimi hovoria)

A - 18.1.3 Túžba učit' sa iné jazyky

A - 18.1.4 Záujem o pozdné štúdium iných cudzích jazykov, okrem tých, ktorých štúdium je momentálne poskytované

A - 18.1.5 Mát' záujem o štúdium jazykov málo rozšírených vo vzdelávaní

A - 18.2 Mat' záujem o vedomé a kontrolované štúdium jazykov

A - 19.2 Zaujímat' sa o techniky učenia sa, o vlastný štýl učenia sa

A - 19.2.1 Pýtat' sa na spôsoby vhodného, konktrétneho porozumenia neznámeho jazyka (kódu)

S - 1 Vediet' pozorovat', analyzovat' jazykové prvky / kultúrne javy vo viac alebo menej známych jazykoch, kultúrach

S - 1.1 Vediet' použivat' / ovládat' postupy pozorovania, analýzy (segmentácie prvkov, ich zoradenia a pospájania)

S - 1.1.2 Vediet' formulovat' hypotézy pri analýze jazykových / kultúrnych javov

$\mathrm{S}-1.1 .3$ Vediet' sa opriet' o známy jazyk, kultúru pri analýze iného jazyka, kultúry

S - 1.1.4 Vediet' simultánne pozorovat' rôzne jazyky / kultúry pre formulovanie predpokladov k analýze javov v určitom jazyku, kultúre

$\mathrm{S}-1$ 1.2.4. Vediet' analyzovat' fonologický systém (izolovat' jednotky, usporiadat' ich)

$\mathrm{S}-1.3$ Vediet' pozorovat', analyzovat' písmo (v jazykoch málo známych alebo neznámych)

$\mathrm{S}$ - 1.3.1 Vediet' izolovat' grafické jednotky (vety, slová, iné minimálne jednotky)

$\mathrm{S}-1.3 .2 \mathrm{~V}$ nutných prípadoch vediet' určit' podobnosti medzi písmom a rečou

$\mathrm{S}$ - 1.3.2.1 Vediet' dešifrovat' text zapísaný v neznámom písme, vediet' oddelit' jednotky a zjednotit' graficko-fonetické podobnosti

S - 2 Vediet' určit' (zistit') jazykové prvky / kultúrne fenomény vo viac alebo menej známych jazykoch / kultúrach

$\mathrm{S}-2.2$ Vediet' určit' (zistit') grafické formy

S - 2.2.1 Vediet' určit' (zistit') základné grafické znaky (písmená, ideogramy, interpunkčné znamienka...)

$\mathrm{S}-2.2 .2$ Vediet' určit' (zistit') morfému alebo slovo v písomnej forme známeho alebo neznámeho jazyka

$\mathrm{S}-2.3$ Vediet' určit' (zistit') slová rôzneho pôvodu na základe rôznych jazykových stôp

S - 2.5.2 Vediet' určit' jazyky na základe grafických znakov

$\mathrm{S}-3.3$ Vediet' vnímat' grafickú blízkost' a vzdialenost' medzi jazykmi

$\mathrm{S}-3.3 .1$ Vediet' vnímat podobnosti a odlišnosti medzi grafickými znakmi 
$\mathrm{S}$ - 3.3.2 Vediet' vnímat' blízkost' a vzdialenost' na úrovni písanej morfémy alebo slova

S - 3.4 Vediet' vnímat' lexikálnu blízkost'

$\mathrm{S}-3.4 .1$ Vediet' vnímat' priamu lexikálnu blízkost'

S - 3.4.2 Vediet' vnímat' nepriamu lexikálnu blízkost' (na základe blízkosti tej istej skupiny výrazov či slov jazykov)

$\mathrm{S}$ - 3.5 Vediet' vnímat' globálnu podobnost' medzi dvoma alebo viacerými jazykmi

$\mathrm{S}-3.5 .1$ Vediet' formulovat' hypotézy týkajúce sa jazykovej podobnosti

$\mathrm{S}$ - 5.2.1 Vediet' porovnat' prvky prenosu z ciel'ového jazyka s prvkami iných jazykov, ktoré sú v mysli súbežne aktivované (a prichádzajú na mysel' pri riešení úlohy)

S - 5.3 Vediet' vykonat' interjazykové prenosy z jedného poznaného jazyka do iného neznámeho jazyka: a) tzv. rozpoznávacie prenosy (pre medzijazykové porozumenie), ktoré určujú vzt’ah medzi identifikovaným prvkom známeho jazyka a prvkom jazyka neznámeho, ktorý je potrebné určit', b) prenosy v etape produkcie do iného jazyka S - 5.3.1 Vediet' vykonat' prenosy tvarov (spustit' proces prenosov) podl'a interfonologických a intergrafematických charakteristík, zákonitostí a nezrovnalostí S - 5.4 Vediet' vykonat' prenosy intrajazykové, ktoré predchádzajú interjazykovým prenosom, alebo po nich nasledujú

S - 7.3.1 Vediet' vyt'ažit' z predchádzajúcich interkultúrnych skúseností v záujme prehíbenia viacjazyčnej interkultúrnej kompetencie

$\mathrm{S}$ - 7.3.2 Vediet' využívat' vedomosti a schopnosti nadobudnuté v jednom jazyku pri štúdiu iného jazyka

$\mathrm{S}$ - 7.3.3 Vediet' využívat' vedomosti a schopnosti nadobudnuté v jednom jazyku pre rozvíjanie vedomostí a schopností $\mathrm{v}$ tomto istom jazyku (na základe porovnávania znakov vnútri jazyka, prostredníctvom indukcie, dedukcie ...)

S - 7.4 Vediet' využit' uskutočnené prenosy (úspešné, neúspešné) medzi jazykmi (známym a neznámym) pri osvojovaní si znakov tohto neznámeho jazyka.

\section{Záver}

V skupine, v ktorej všetci hovorili anglickým jazykom, čast' z nich používa jazyk francúzsky a čast’ jazyk španielsky, sme pozorovali zvýšenú motiváciu o učenie sa románskych jazykov. Táto motivácia sa objavila po úspešnom zvládnutí prvej aktivity. Žiaci končiacich ročníkov začali rozmýšl'at' o učení sa d'alších dvoch románskych jazykov a o zapájaní kl'účových kompetencií v snahe dorozumiet' sa v neznámom kontexte. Boli nadšení z úspechu, s ktorým sa stretli počas riešenia vzdelávacích viacjazyčných problémov ponúknutých $\mathrm{v}$ aktivitách. Možno konštatovat', že obe aktivity sú hodnotené nadpriemerne deskriptormi FREPA a že prieskum, ktorý sme realizovali, prvotne dokazuje, že správne ovládanie techník pedagogickej nápovedy a správneho výberu obsahu vzdelávania pozitívne vplýva na rozvoj motivácie a na riešenie jazykovo-komunikačných problémov v kontexte románskej interkomprehnezie a v kontexte viacjazyčnosti.

\section{Bibliographic references}

ABDALLAH-PRETCEILLE, M. - PORCHER, L. 1996. Education et communication interculturelle. Paris: P.U.F

ANDREJCAKOVA, M. 2010. Le mot polysemique: comment cerner son unite ? In Philologia 20. Bratislava: Univerzita Komenskeho, pp. 17-25. ISBN 978-80-2232803-6

BERESOVA, J. 2009. Didaktika anglickeho jazyka. Bratislava: MPC. ISBN 978-808052-330-5. 
BERNAUS, M. - ANDRADE, A.-I. - KERVRAN, M. - MURKOWSKA, A. TRUJILLO SAEZ, F. 2007. Plurilingual and Pluricultural Awareness in Language Teacher Education. A training kit. Council of Europe. ISBN 978-92-871-6230-4 BIALYSTOK, E. 1988. Factors in the Growth of Linguistic Awareness. In: Children development, c. 57, s. 498-510.

BIALYSTOK, E. 2007. Cognitive Effects of Bilinguism: How Linguistic Experience Leads to Cognitive Change. In: International Journal of Bilingual Education and Bilinguism, č. 10/3, s.210-223.

BIALYSTOK, E. 1988. Levels of bilingualism and levels of linguistic awareness. In Developmental psychology. vol. 24.

BIROVA, J. 2008. Les cas de l'EFLEIALE dans le contexte du systeme scolaire en Slovaquie. In: Fenclova, M. - Horova, H. (eds.): Le français - deuxieme langue etrangere - La didactique integree des langues etrangeres. Plzen: Katedra romanskych jazyku, Filozoficka fakulta, Zapadoceska univerzita v Plzni,. s. 77-83.

BIROVA, J. - BUBAKOVA J. 2011. Multikultura, plurilingvizmus a preklad Charty plurilingvizmu. In: XLinguae. ISSN 1337-8384, Vol. 3, no. 4, s. 51-58.

BORISOVA, O.V. - VASBIEVA, D.G. 2016. Prospects for the development of continuing vocational education on the basis of Russian universities. Slavonic Pedagogical Studies Journal, vol. 5 n.2, pp. 443-454. ISSN 13398660. doi: 10.18355/PG.2016.5.2.443-454

BYRAM, M. 1997. Teaching and Assessing Intercultural Communicative Competence. Clevedon, Philadelphia: Multilingual Matters,

CANDELIER, M. et al. 2011. Le CARAP, Un cadre de reference pour les approches plurielles des langues et des cultures. Graz: CELV, Conseil de 1'Europe. (http://carap.ecml.at, konzultovane 12.11.2011)

CANDELIER, M. et al. 2009. Banque de materiaux didactiques (BMD)/Teaching materials bank. 132 cards. (http://carap.ecml.at, konzultovane 12.11.2011)

CANDELIER, M. 2009. A travers les langues et les cultures. (http://ecml.at/mtp2/ALC/pdf/pdescC4F.pdf

http://www.europe-avenir.com/TI_Candelier.doc, konzultovane 12.11.2011)

COLLES, L. - DUFAYS, J.-L. - THYRION, F. 2006. Quelle didactique de l'interculturel dans les nouveaux contextes du FLE/S ? Belgicko: Proximites E.M.E. COSTA, A. 2006. Speech Production in Bilinguals. In: Bhatia, T.K. - Richie, W.C. (eds.): Handbook of Bilingualism. Malden: Blackwell, s. 201-223.

COSTE, D. - MOORE, D. - ZARATE, G. 2009. Competence plurilingue et pluriculturelle. Strasbourg: Division des Politiques linguistiques.

DUCHOVICOVA, J. - SABO, A. - PETROVA, G. 2015. Facilitation of selfconsciousness of academically gifted students [Facilitacia sebavnimania akademicky nadanych ziakov]. In Slavonic Pedagogical Studies Journal, vol. 4. n. 2., pp. 113-135. ISSN 1339-8660. doi: 10.18355/PG.2015.4.2.113-135

GRICE, H. P. 1975. Logic and Conversation. In: Cole, P. - Morgan, J.L. (eds.) Speech Acts. New York: Academic Press. s. 41-58.

GROSJEAN, F. 1995. A Psycholinguistic Approach to Code-Switching. In: Milroy, L. - Muysken, P.: One speaker, two languages. Cambridge: Cambridge University Press, s. 259-275.

GUDYKUNST, B. W. - KIM, Y. Y. 1997. Communicating with Strangers: an Approach to Intercultural Communication. New York: The McGraw-Hill Companies, Inc.,

HAWKINS, E. 1984. Awareness of Language. An Introduction. Cambridge: CUP. CHARNET, C. 2004. Des mots pour s'entendre. Le cas de l'interculturel. In: LIDIL: La rencontre interculturelle 2004, Grenoble US, s.105-126. ISSN 1146-6480.

JAROSOVA, A. - BUZASSYOVA, K. 2011. Slovnik sucasneho slovenskeho jazyka. Bratislava: Veda, s. 391. ISBN 978-80-224-1172-1. 
KOLLAROVA, E. 2004. Kulturologicka kompetencia ucitela - rusistu a svet jazyka. In: Ries, L. - Kollarova, E. (eds.): Svet cudzich jazykov dnes. Inovacne trendy v cudzojazycnej vyucbe. s.45-74.

KRAMSCH, C. 1991. Interaction et discours dans la classe de langue. Crédif-DidierHatier.

LEFEBVRE, M. - L. HILY, M.-A. 1997. Les situations plurilingues et leurs enjeux. Canada: L'Harmattan. ISBN 2-89489-031-1.

GUTMAN, E. V. - MASALIMOVA, A. R. - SHAIDULLINA, A. R. NIZAMIEVA, A. M. - MUKHAMADIEVA, A. H. 2014. Foreign language discipline integrative potential in the students' research competence development. In American Journal of Applied Sciences, 11, pp. 1099-1103.

MALOVECKY, M. 2014. Ako dalej v hladani metody v kontrastivnej lingvistike? In Hladanie metody v kontrastivnej lingvistike. Bratislava: Univerzita Komenskeho, pp. 148-152. ISBN 978-80-223-3772-4.

MARKEY, D. - PORCHNEVA, E. 2008. Enseigner les belles lettres dans un pays non-francophone: le cas de la nouvelle correspondance française administrative et d'affaires. In : Dialogues et cultures n. 53. Belgicko. ISSN 0226-6881.

MASALIMOVA, A. R. - IKRAMOVA, G. D. - SHAIDULLINA, A. R. GUBAIDULliNA, G. T. - APRAKSINA, N. D. 2014. Distant in-company foreign language learning involving university student-tutors. In American Journal of Applied Sciences, 11, pp. 1123-1127.

MISTRIK, E. 2001. Od kulturnej tolerancie ku kulturnej identite. Ucebne texty pre multikulturnu vychovu. Bratislava: Iris.

MORGENSTERNOVA, M. - SULOVA, L. - SCHOLL, L. 2011. Bilinguismus a interkulturni komunikace. Praha: Wolters Kluwer CR, a.s.

ORGONOVA, O. 1991. Falosni priatelia (faux-amis) v jazykovych kontaktoch slovenciny s francuzstinou. In: Studia academica slovaca 20. s.193-212. ISBN 80050095 .

PAOLINI, M. 2015. La natura del segno terminologico. In Philologia, XXIV, 1, pp. 29-34.

PORTER, R. E. - SAMOVAR, L. A. 1988. Approaching Intercultural Communication. In: Intercultural Communication. A Reader. 5th edition. Belmont: Wadsworth, pp. 15-30.

PRUCHA, J. 2001. Multikulturni vychova: Teorie, praxe, vyzkum. Praha: Nakl. ISV 2001. ISBN 80-85866-72-2.

SERCU, L. 2000. Acquiring Intercultural Communicative Competence from Textbooks. Leuven University Press.

SINGER, R. M. 1987. Intercultural Communication: A Perceptual Approach. Englewood Cliffs, New Jersey: Prentice Hall, Inc.

SERR. Spolocny europsky referencny ramec pre jazyky. 2006. Bratislava: SPU, ISBN 80-855756-93-5.

STEFANIK, J. 2000. Jeden clovek, dva jazyky. Bratislava: Academic Electronic Press.

TRUJILLO, S.F. 2005. En tornoa la interculturalidad: Reflexiones sobre cultura y communicacion para la didactica de la lengua. In: Porta Linguarum 4, pp. 23-39.

TUREK, I. 2008. Didaktika. Bratislava: Iura Edition.

VANCOVA, A. - KASTELOVA, A. 2016. The current research view on the issue of special educational diagnostics, special educational counseling and early intervention for children with disabilities in Slovakia. In Turkish Online Journal of Educational Technology, Vol. December, SpecialIssue, pp. 1401-1412. ISSN 1303-6521

VERNARCOVA, J. 2015. Document Body image and self-esteem through the school curriculum. In Turkish Online Journal of Educational Technology, Vol. Special Issue. pp. 96-99. ISSN 1303-6521 
Co je to viacjazycnost? 2014. In: Europska komisia. [03.01.2015]. Available on line: http://ec.europa.eu/slovensko/news/viacjazycnost/co_je_viacjazycnost_sk.htm Konsolidovane znenie Zmluvy o Europskej unii a Zmluvy o fungovani Europskej unie. Charta zakladnych prav europskej unie. 2010. [03.01.2015]. Available on line: http://europa.eu/pol/pdf/qc3209190skc_002.pdf\#page=18

Štúdia je výstupom zahraničného kultúrno-edukačného grantu ziskaného $z$ Univerzitnej vedeckej agentúry pre frankofóniu AUF v roku 2016 pod názvom: Consolidation des cours en francais. Convention de projet - 2016.

assoc. prof. Jana Birova, $\mathrm{PhD}$.

Mgr. Nina Mockova

Department of Romance languages and literatures

Faculty of Education, Comenius University

Racianska 59

Bratislava, Slovakia

assoc. prof. Zdena Kralova, $\mathrm{PhD}$.

Mgr. Zuzana Simkova

Department of Language Pedagogy and Intercultural Studies

Faculty of Education

Constantine the Philosopher University

Dražovská 2

Nitra, Slovakia

Mgr. Martina Lipkova

Faculty of Mechanical Engineering

Slovak University of Technology

Námestie slobody 17

Bratislava, Slovakia 